\title{
Management of Sugar Industrial Wastes through Vermitechnology
}

\author{
Sartaj Ahmad Bhat ${ }^{1}$, Jaswinder Singh ${ }^{2}$, Adarsh Pal Vig ${ }^{{ }^{*}}$ \\ ${ }^{1}$ Department of Botanical and Environmental Sciences, Guru Nanak Dev University, \\ Amritsar, Punjab, India. \\ E mail: sartajbhat88@gmail.com \\ ${ }^{2}$ PG Department of Zoology, Khalsa College, Amritsar, Punjab, India. \\ E mail: singhjassi75@yahoo.co.in
}

*Corresponding author: Tel.: +91-9417062796; E mail: dr.adarshpalvig@gmail.com

Keywords: vermicomposting; sugar industry; earthworms; nutrients; recycling

\begin{abstract}
The present paper discusses the role of earthworms in recycling of sugar industrial wastes. The wastes generated from sugar industry are pressmud, bagasse, bagasse fly ash, sugar cane trash, sugar beet mud, sugar beet pulp, molasses etc. These wastes when mixed with other organic substrates become ideal mixtures for growth of earthworms. These wastes if stored in open field's causes contamination in the environment and may cause several diseases in public health. But the governments have been unable to tackle the menace of solid waste pollution due to dearth of appropriate technologies, finance and space. Therefore, environment friendly and cost effective technologies for nutrient recycling or remediation of wastes are being advocated as an alternative means for conserving and replenishing natural resources of the ecosystems. Vermicomposting is one such technology that synergises microbial degradation with earthworm's activity for reducing, reusing and recycling waste materials in a shorter span of time. Earthworm technology can convert sugar industrial wastes into valuable fertilizing material. The final product (vermicompost) produced during the process of vermicomposting is nutrient rich organic fertilizer with plant available nutrients such as nitrogen, potassium, calcium and phosphorus. In the present study an attempt has been made to document the role of earthworms in reuse of sugar industry waste.
\end{abstract}

\section{Introduction}

Waste recycling and its use as a soil conditioner/agricultural purpose is the best method for the management of industrial wastes. India is the second-largest producer of world's sugar after Brazil and largest consumer of the world [1]. According to United Nations Department of Agriculture (USDA), Global sugar production for 2015-16 is 172 million metric tons while India producing 28.5 million tons. During the processing of sugar, different kind of wastes is generated like pressmud, bagasse, sugar cane trash, sugar beet mud, pulp, molasses etc. [2-5]. These wastes are potential pollutants unless recycled. Pressmud is the solid waste obtained in the clarification process of sugarcane juice. Each ton of processed sugarcane produces about 0.03 ton of pressmud [6]. Pressmud is insoluble, takes long time for natural decomposition and generates intense heat with foul odor [7]. Bagasse is the fibrous waste obtained during the process of sugarcane juice extraction. Bagasse waste constitutes $50 \%$ cellulose, $25 \%$ hemicelluloses and $25 \%$ lignin [8]. About 0.30 ton of bagasse waste is obtained from 1 ton of sugarcane [9]. About 27\% of world's sugar is produced from sugar beets grown in temperate regions. The wastes generated from sugar beets are sugar beet mud, sugar beet pulp and molasses [4]. Western European generates more than 14 million tonnes of Sugar beet pulp every year [10-11]. The addition of lime into the raw juice of sugar beet is transformed into sugar beet mud. The sugar mill stores these wastes in open fields, which pollutes the natural environment of that area. Vermicomposting could be an alternative technology for converting sugar industry wastes into valuable manure. Earthworms ingest, break and digest waste and converts into finer, humified, microbially active material by the activity of earthworms and microbes known as vermicompost [12]. Vermicompost is increasingly considered in agriculture and horticulture as a promising alternative to chemical fertilizers [13]. The nutrient 
content $(\mathrm{N}, \mathrm{P}, \mathrm{K}, \mathrm{Ca}, \mathrm{Na})$ in vermicompost is generally higher than compost produced from without earthworms [14]. The vermicompost is generally granular in shape due to earthworm fragmentation and decomposition of material [15]. In the present study an attempt has been made to document the work done in vermicomposting of sugar industrial wastes and its nutrient status in final product i.e vermicompost.

\section{Types of waste and their reuse}

In sugar industry, sugar cane and sugar beets are used for sugar production. The solid wastes generated from sugar cane are pressmud, bagasse, bagasse fly ash whereas, sugar beet mud and sugar beet pulp are generated from sugar beets. Bagasse is used as a fuel to generate electricity. Bagasse fly ash, pressmud and sugar beet mud are disposed off in open fields which pollute the environment of that area. Sugar beet pulp is used as a ruminant feed. Vermicomposting technique as a nature-friendly process to degrade these wastes into nutrient rich manure has been used at vermicomposting unit of Guru Nanak Dev University campus Amritsar. The initial and final vermicomposted sugar industrial wastes (Pressmud, bagasse, sugar beet mud and sugar beet pulp) that were processed at our vermicomposting unit are shown in figure $1(\mathrm{a}-\mathrm{h})$.

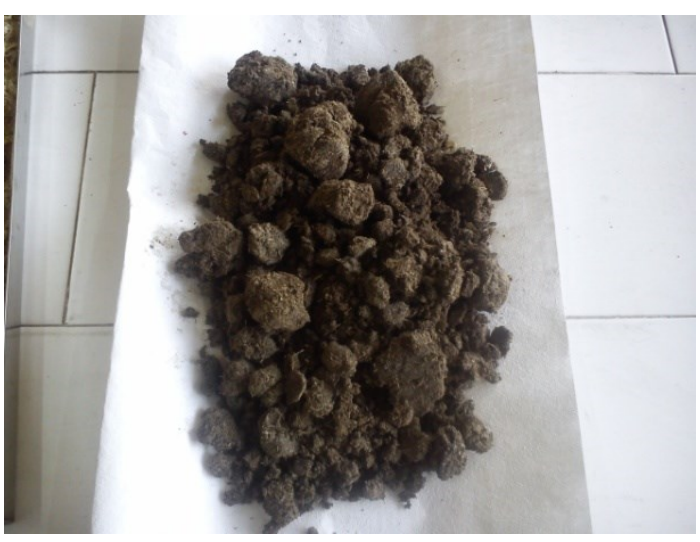

(a) Initial Pressmud waste

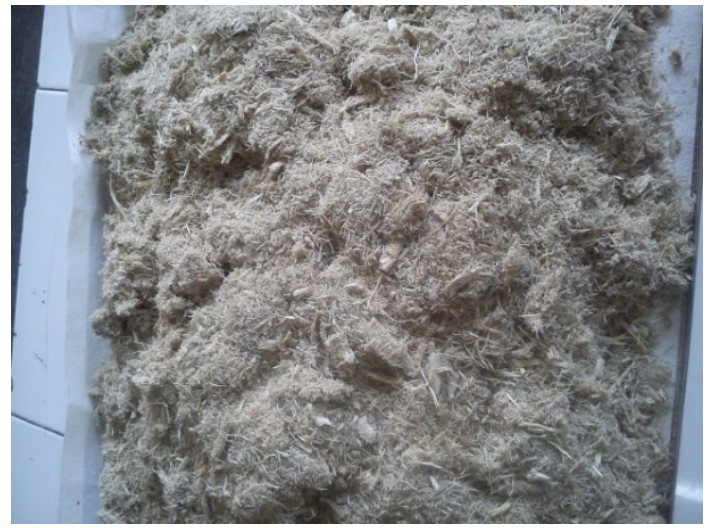

(c) Initial bagasse waste

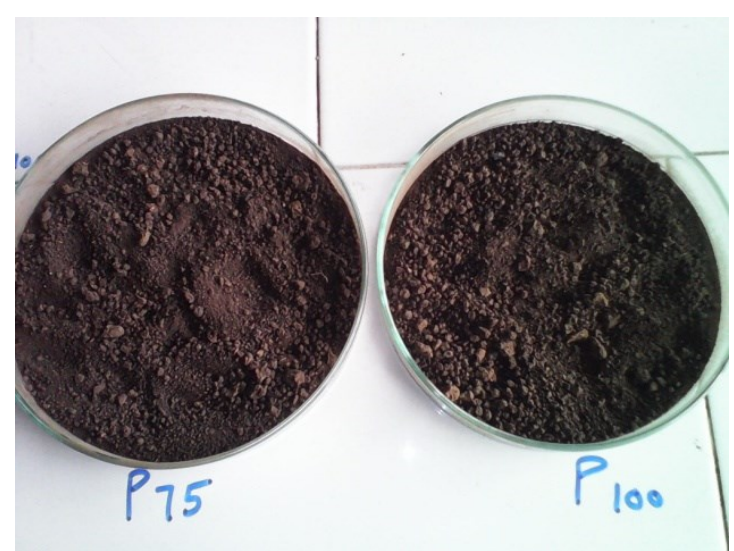

(b) Final vermicompost

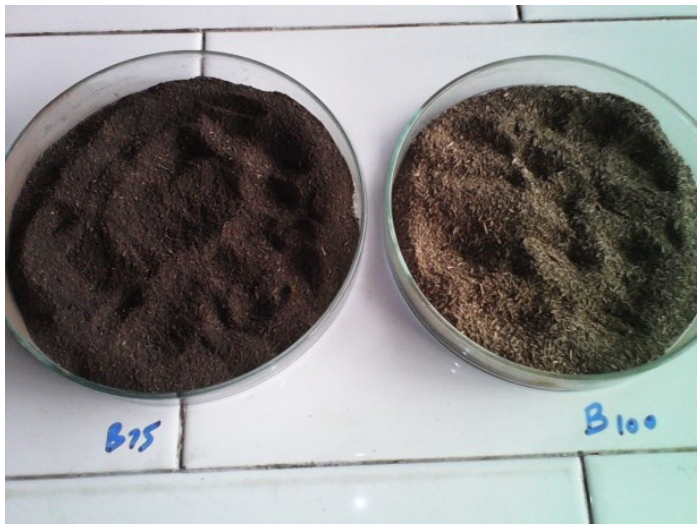

(d) Final vermicompost 


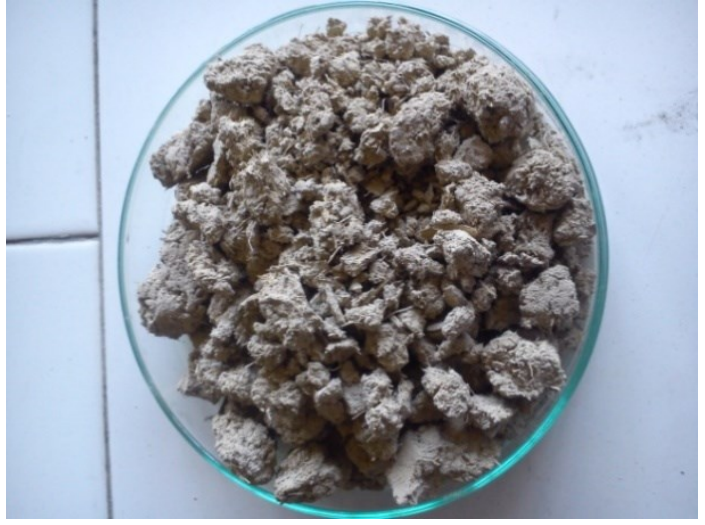

(e) Initial sugar beet mud waste

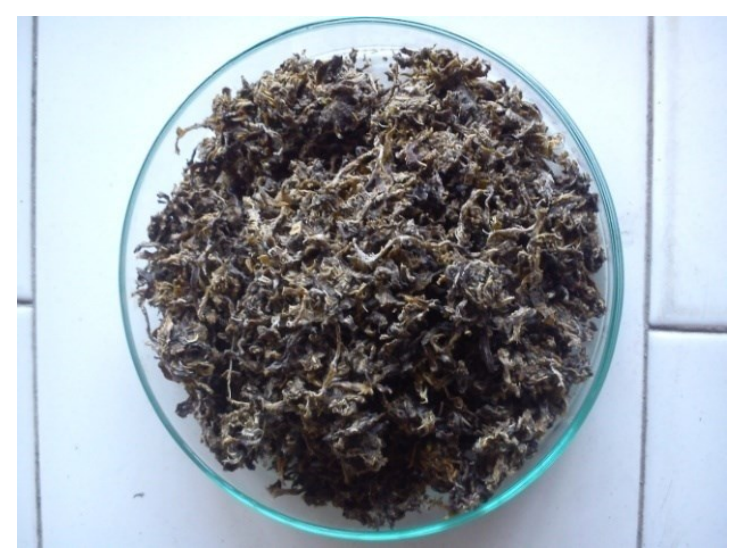

(g) Initial sugar beet pulp waste

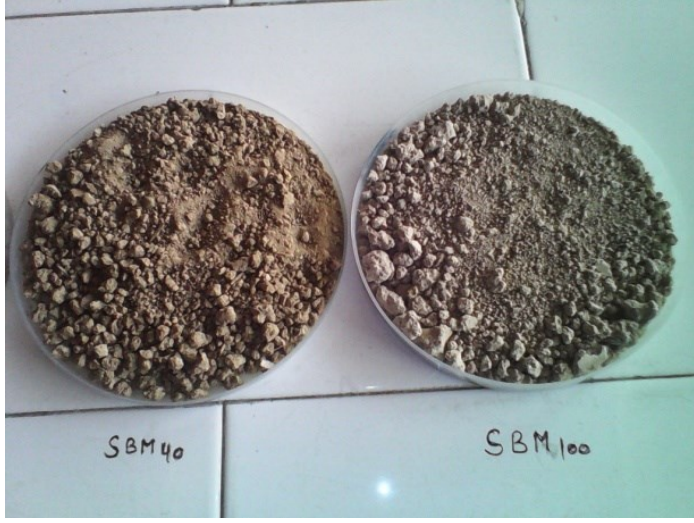

(f) Final vermicompost

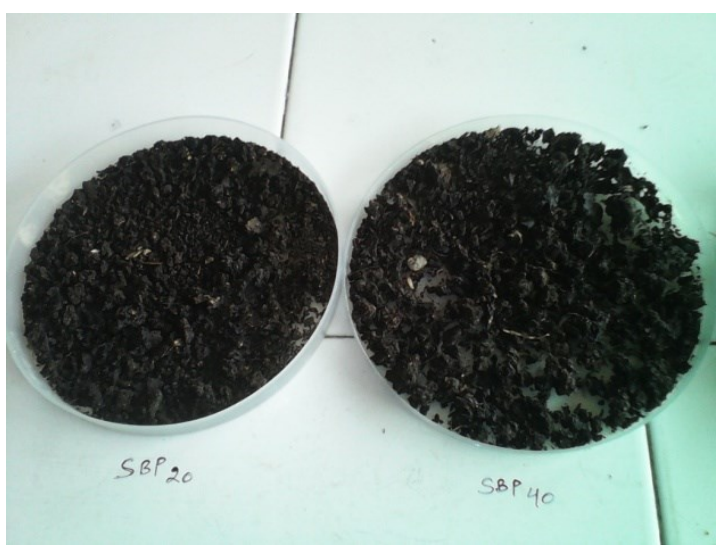

(h) Final vermicompost

Figure 1: Initial and final vermicomposted sugar industrial wastes (a-h)

\section{Types of earthworms and options for recycling/management}

On the basis of feeding and burrowing activities, earthworm species have been classified into three categories: epigeic (Greek for "upon the earth") anecic (Greek for "up from the earth" or "out of the earth"), and endogeic (Greek for "within the earth") worms. Out of these three types of earthworms, epigeic species (most commonly Eisenia fetida) shows good potential for vermicomposting as it has a high tolerance to a wide range of environmental conditions, higher rates of decomposition of organic substances and high reproductive rate and short life cycle. The other commonly used earthworm species for vermicomposting are E. andrei, Eudrilus eugenie, Lumbricus rubellus, L. castaneus, Bimastus eiseni, B. minusculus, Drawida modesta, Dendrodrilus rubidus, Dendrobaena veneta and perionyx excavates. The degradation process and rate of vermicomposting depends on physical factors (temperature, moisture, particle size, shade, aeration) chemical factors ( $\mathrm{C}: \mathrm{N}$ ratio, $\mathrm{pH}$, calcium) and biological factors (microorganisms, feed material and earthworm species and density). In vermicomposting process, the optimum range of temperature is $25-45^{\circ} \mathrm{C}$ but $24{ }^{\circ} \mathrm{C}$ is the best temperature for vermicomposting. Moisture level should be maintained between 50-60\%. Many researchers have successfully utilized sugar industrial wastes for large scale vermicomposting. The vermicomposting process of sugar industrial wastes are divided into two parts viz. Nutrients/ chemical changes of wastes and growth studies of earthworms.

\section{Nutrients/chemical changes of wastes}

Earthworm increases the nutrient content of the sugar mill wastes. Many researchers have successfully managed sugar industrial wastes into a fertilizing material by earthworm technology. Reddy and Shantaram [16] utilized sugar mill wastes (pressmud, bagasse and cane trash) using earthworm Eisenia fetida. The authors reported that final vermicompost has two fold more nitrogen 
content than microbial composting and suggested vermitechnology for efficient management of sugar industrial by-products. Parthasarathi [17] reported that the vermicast obtained from fresh pressmud by using earthworm Lampito mauritii and Eudrilus eugeniae showed higher microbial population and increased mineralization than undigested pressmud. The fresh pressmud vermicast supports soil and improves soil fertility. Sen and Chandra [7] reported rapid decrease in lignocellulosic content and $\mathrm{C}: \mathrm{N}$ ratio during vermicomposting of sugar industrial wastes (pressmud, bagasse, trash). The decrease in carbon to nitrogen ratio indicates decomposition of organic matter and compost maturity in final products of vermicomposting. Nitrogen increased from initial to final vermi products. Sangwan et al [18] reported vermicomposting of pressmud mixed with horse dung using earthworm E. fetida.. The nutrient content (nitrogen, phosphorus, potassium) was more in final products of vermicomposting as compared to initial raw material and concluded that pressmud can be managed into useful fertilizing product, if mixed at maximum 50\% with horse dung. Sangwan et al [19] also reported vermicomposting of sugar mill sludge mixed with biogas plant slurry using earthworm E. fetida. The results also showed reduction in $\mathrm{pH}$, total organic carbon, carbon to nitrogen ratio and total potassium, but increase in total nitrogen and total phosphorus was observed in the final feed mixtures. The results indicated that sugar mill sludge can be managed into a fertilizing material if mixed $30-50 \%$ with biogas plant slurry.

Earthworm E. fetida, E. eugeniae and P. excavates employed in mono and polycultures to manage pressmud has been investigated by Khwairakpam and Bhargava [12]. The results showed reduction in $\mathrm{pH}$, total organic carbon and carbon to nitrogen ratio but increase in nitrogen, phosphorus, electrical conductivity, potassium, calcium and sodium. The results revealed that the maximum growth, nutrient content and decomposition of waste was observed in polycultures as compared to monoculture reactor. Prakash and Karmegam [20] reported the vermicomposting of pressmud sludge mixed with cattle dung (1:1) by using earthworm Perionyx ceylanensis. Vermicomposting with $P$. ceylanensis resulted in significant reduction of $\mathrm{pH}$, total organic carbon and carbon to nitrogen ration but increase in nitrogen, phosphorus and potassium. The study also reported that the populations of bacteria, fungi and actinomycetes increased in the presence of earthworms. The results indicated that the pressmud can be converted into nutrient and microbe rich vermicompost if mixed in 1:1 ratio with cow dung using earthworm $P$. ceylanensis. Kumar et al [21] reported the vermicomposting of sugar mill wastes (pressmud, bagasse, sugarcane trash) using earthworm Drawida willsi. The authors first pre-decomposed the sugar mill wastes with microbes for 30 days to shorten stabilization time and then followed vermicomposting for 40 days. The results revealed that both processes (microbe pre-decomposting and vermicomposting) resulted in reduction of total organic carbon and carbon to nitrogen ratio and increase in nitrogen, phosphorus and potassium content.

Sangwan et al [22] reported the vermicomposting of pressmud sludge mixed with cow dung using earthworm E. fetida. The results shows the reduction in $\mathrm{C}: \mathrm{N}$ ratio and total organic carbon and increase in nitrogen, phosphorus and calcium in the final feed mixtures. The study concluded that if pressmud is mixed with upto $50 \%$ cow dung it will be converted into high quality manure. Honarvar et al [23] reported composting and vermicomposting of sugar beet mud. The final vermicompost was superior (in terms of chemical characteristics) to the compost produced from sugar beet wastes. Nutrients like phosphorus, zinc and nitrogen were increased whereas saltiness was decreased by $50 \%$ in the final vermicompost. Cynthia and Rajeshkumar [24] utilized sugar mill effluent amended with cow dung, straw and biodegradable waste using enecic earthworm Lampito mauritii. The result shows that the final vermicompost of the effluent treated bed was rich in nitrogen, phosphorus and potassium than the control. The study also revealed that the earthworm L. mauritii have high protein content and are suitable for fish feed, poultry and fish bait. Pandit and Maheshwari [25] reported vermicomposting of pressmud and bagasse mixed with jeevamrutham using earthworm E. fetida. The authors first pretreated sugar mill wastes with effective microbial suspension (jeevamrutham) for 15 days and then followed vermicomposting by E. fetida for six weeks. The results revealed that the final feed mixtures of vermicomposting were rich in nitrogen, phosphorus, potassium, calcium, magnesium, sodium and micronutrients ( $\mathrm{Zn}, \mathrm{Mn}, \mathrm{Fe}, \mathrm{Cu}, \mathrm{Al})$. The 
study concluded that the pretreatment with jeevamrutham at 2:1 ratio increased decomposition and bioconversion into a rich manure (vermicompost).

Nayazi and Chaurasia [26] reported vermicomposting of flyash mixed with pressmud sludge using earthworm E. fetida. The results showed reduction in temperature, $\mathrm{pH}$, total organic carbon, $\mathrm{C}: \mathrm{N}$ ratio and fecal coliforms, but increase in nitrogen, phosphorus, potassium and electrical conductivity. Heavy metals showed $35-50 \%$ reduction in the final feed mixtures of vermicomposting. The study indicated that the flyash can be managed into a nutrient rich material if mixed 40-60\% with pressmud. Bhat et al [2] reported the genotoxicity reduction and vermicomposting of pressmud sludge amended with cow dung using E. fetida. The results showed that the nutrients like $\mathrm{pH}$, electrical conductivity, nitrogen, phosphorus and sodium increased from initial to final feed mixtures while organic carbon, $\mathrm{C}: \mathrm{N}$ ratio and potassium declined in all the products of vermicomposting. The study also showed that the vermicompost produced from E. fetida reduces the genotoxicity of pressmud sludge.

Pandit and Maheshwari [27] reported vermistabilization of sugar industrial byproducts (pressmud, bagasse, sugarcane trash) mixed with cow dung and jeevanrutham using earthworm E. fetida. The final obtained vermicompost was rich in nitrogen, phosphorus, potassium, sodium, calcium and magnesium, while $\mathrm{pH}$, electrical conductivity, organic carbon and $\mathrm{C}: \mathrm{N}$ ratio decreased from initial to final products of vermicomposting. Maximum nutrient content and growth of earthworms were observed in reactor R5 (bagasse+Jeevanrutham). Bhat et al [3] reported vermicomposting of bagasse waste amended with cattle dung using earthworm E. fetida. The results revealed that the nutrients like nitrogen, phosphorus, sodium increased from pre-vermicompost to post-vermicompost, while organic carbon and $\mathrm{C}: \mathrm{N}$ ratio decreased in all the end products of bagasse waste. The study concluded that the vermicomposting could be introduced as efficient technology to convert bagasse waste into nutrient rich manure. Bhat et al [4] also reported vermicomposting of sugar beet mud and pulp amended with cattle dung using earthworm E. fetida. Nutrients like nitrogen, phosphorus, sodium increased from initial to final while organic carbon, $\mathrm{C}: \mathrm{N}$ ratio and electrical conductivity declined in all the final products of vermicomposting. From the genotoxicity study, the results indicated that the vermitechnology reduced the genotoxicity potential of sugar beet mud. Shah et al [28] conducted vermicomposting of sugarcane baggase, pressmud, along with sugar mill effluent and farm manure. The final vermicompost of sugar mill wastes produced high quality manure with enriched nutrients $(\mathrm{N}, \mathrm{P}, \mathrm{K}, \mathrm{Ca}, \mathrm{Na})$. The authors concluded that the vermicomposting of sugar mill wastes produced good quality material with enriched nutrients as compared to composting technique.

A number of reasons can be discussed for the changes in chemical composition during vermicomposting. The increase in nutrient content in the final vermicompost may be due to the earthworm activity such as addition of mucus, nitrogenous excretory substances, growth-stimulating hormones, microbe-mediated transformation and enzymes available in worms [22]. Earthworms and microbes uses large portion of carbon as sources of energy and nitrogen for building cell structure brings about decomposition of organic carbon [29]. In vermicomposting process, the loss of organic carbon can be attributed to the loss of organic matter from feed mixtures as carbon dioxide through earthworms and microbial respiration as well as assimilation by microbial biomass [30]. In vermicomposting process, a decline in $\mathrm{C}: \mathrm{N}$ ratio to less than 20 indicates an advanced degree of organic matter stabilization [31] and reflects a satisfactory degree of maturity of organic wastes [32]. Decrease in $\mathrm{C}: \mathrm{N}$ ratio in vermicomposting process may be due to the microbial respiration and the mineralization of the organic compounds, which are reducing the weight and volume in the mixtures, and increases the total nitrogen content $[2,33]$.

\section{Growth studies}

Various studies are available to support the growth and development of the earthworms using sugar industrial wastes amended with other substrates. Many researchers have observed that sugar industrial wastes amended with cattle dung is desirable for growth and reproduction of earthworms. Parthasarathi [34] reported $65-67 \%$ moisture content of pressmud is desirable for 
growth and reproduction of Perionyx excavates. The results revealed that $65-67 \%$ moisture content enhanced microbial growth and nutrient content (nitrogen, phosphorus, potassium) in fresh vermicompost, whereas $55-57 \%$ and $75-77 \%$ moisture content were inadequate for growth and reproduction of earthworms. Sangwan et al [18] revealed that $10 \%$ of pressmud sludge increased earthworm growth and cocoon production. However increasing concentrations of pressmud sludge affected growth and reproduction of earthworms. Sangwan et al [19] observed that the earthworm E. fetida grow and reproduce in $20 \%$ pressmud $+80 \%$ biogas plant slurry feed mixture which was higher from other feed mixtures. Suthar [35] compared pilot scale vermicomposting and small scale vermicomposting reactors in terms of nutrient content and earthworm growth parameters during vermicomposting of sewage sludge amended with sugarcane trash. The study revealed that earthworm growth and nutrient content was more in small scale vermireactor as compared to pilot scale vermireactor and may be due to microclimatic variability in feed mixtures. Bhat et al [2] managed pressmud sludge through E. fetida and observed that the maximum growth and reproduction was observed in the 25:75 (pressmud: cow dung) feed mixture. Bhat et al [3] also managed baggase waste amended with cattle dung through earthworm E. fetida. The results showed that the minimum mortality and highest growth of worms were observed in 50:50 (bagasse:cattle dung) mixture. Bhat et al [4] studied vermicomposting of sugar beet mud and pulp amended with cattle dung using E. fetida. Maximum growth of earthworms was reported in $20 \%$ mixture of sugar beet mud and $10 \%$ mixture of sugar beet pulp.

The different sugar mill wastes increased growth rate, worm biomass and reproduction of earthworms due to the uptake of nutrients available in these wastes. Loh et al., [36] studied that biomass gain and cocoon production was more in cattle dung than in goat manure and thus cattle dung provided a more nutritious and friendly environment to the E. fetida than goat manure. The feed substrates which provides earthworms with sufficient amount of easily organic matter and nonassimilated carbohydrates, favour the growth and reproduction of the earthworms [37]. Suthar, [38] reported that in addition to the biochemical properties of waste, the microbial biomass and decomposition activities during vermicomposting are also important in determining the worm biomass and cocoon production. Figure 2 shows the suitability of earthworm Eisenia fetida as ecological engineer while degrading pressmud sludge and cattle dung in the ratio of 50:50.

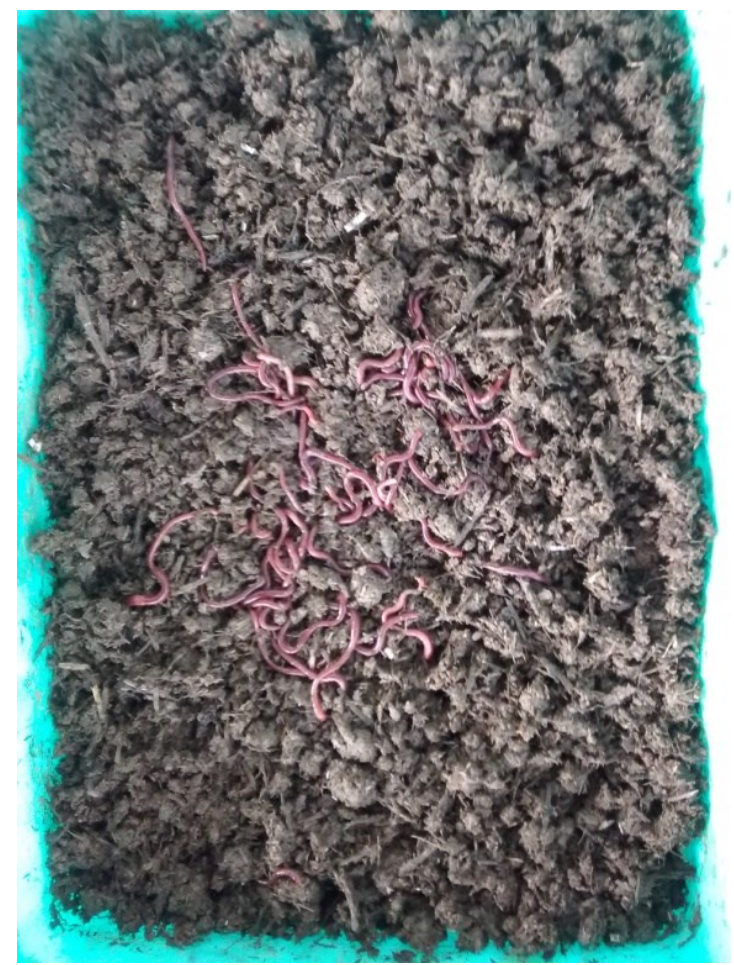

Figure 2. Ecological Engineer (Eisenia fetida) growing well in the pressmud and cattle dung mixture (50:50). 


\section{Conclusions}

From the present review, it can be concluded that vermitechnology is eco-friendly, costeffective and safe technology, for recycling of all kinds of sugar industrial wastes. In most of the studies the best growth, biomass and reproduction of earthworms were observed in 50:50 mixtures of sugar industrial wastes amended with cattle dung having moisture content $60-70 \%$. Vermicomposting also resulted in the drop of $\mathrm{pH}$, organic carbon and $\mathrm{C}: \mathrm{N}$ ratio while increases the nitrogen, potassium, phosphorus and calcium nutrients making it a better manure. Utilization of these waste materials for productivity process is important for both economical and environmental reasons. Vermicomposting is an important aspect, as it converts waste to wealth by using cheap eco-friendly option with the activity of earthworms. The conclusion can be drawn as instead of looking for solid waste disposal, the waste will be converted into a valuable wealth with the help of earthworms.

\section{Competing interests}

The authors declare that they have no competing interests.

\section{Authors contributions}

SAB: Collected, reviewed the literature and drafted the manuscript. JS: Formulated the structure and sequence as well as improved the quality of the manuscript. APV: Provided guidance, resources, helped in designing, and finalized the manuscript with his personal inputs. All authors read and approved final manuscript.

\section{Acknowledgement}

Sartaj Ahmad Bhat is thankful to the UGC, New Delhi for UGC-BSR Fellowship and Department of Botanical and Environmental Sciences, Guru Nanak Dev University, Amritsar, Punjab, India for providing research facility.

\section{References}

[1] P.J.M. Rao, Comparative performance of cane sugar industry in seven countries. Coop. Sugar. 37 (2005) 49-52.

[2] S.A. Bhat, J. Singh, A.P. Vig, Genotoxic assessment and optimization of pressmud with the help of exotic earthworm Eisenia fetida. Environ. Sci. Pollut. Res. 21 (2014) 8112-8123.

[3] S.A. Bhat, J. Singh, A.P. Vig, Potential utilization of bagasse as feed material for earthworm Eisenia fetida and production of vermicompost. Springerplus. 4 (2015) 11.

[4] S.A. Bhat, J. Singh, A.P. Vig, Vermistabilization of sugar beet (Beta vulgaris L) waste produced from sugar factory using earthworm Eisenia fetida: Genotoxic assessment by Allium cepa test. Environ. Sci. Pollut. Res. 22 (2015) 11236-11254.

[5] M. Balakrishnan, V.S. Batra, Valorization of solid waste in sugar factories with possible application in India: A review. J Environ. Manage. 92 (2011) 2886-2891.

[6] R.L. Yadav, S. Solomon, Potential of developing sugarcane by-products based industries in India. Sugar Tech. 8 (2006) 104-111.

[7] B. Sen, T.S. Chandra, Chemolytic and solid-state spectroscopic evaluation of organic matter transformation during vermicomposting of sugar industry wastes. Bioresour. Technol. 98 (2007) 1680-1683.

[8] S. Ezhumalai, V. Thangavelu, Kinetic and optimization studies on the bioconversion of lignocellulosic material into ethanol. Bioresources. 5 (2010) 1879-1894. 
[9] J.A. Pessoa, I.M. de Manchilha, S. Sato, Evaluation of sugar cane hemicellulose hydrolyzate for cultivation of yeasts and filamentous fungi. J. Ind. Microbiol. Biot. 18 (1997) 360-363.

[10] V.M. Dronnet, C.M.G.C. Renard, M.A.V. Axelos, J.F. Thibault, Binding of divalent metal cations by sugar-beet pulp. Carbohyd. Polym. 34 (1997) 73-82.

[11] C. Gerente, P. Couespel du Mesnil, Y. Andres, J.F. Thibault, P. Le Cloirec, Removal of metal ions from aqueous solution on low cost natural polysaccharides-sorption mechanism approach. React. Funct. Polym. 46 (2000) 135-144.

[12] M. Khwairakpam, R. Bhargava, Bioconversion of filter mud using vermicomposting employing two exotic and one local earthworm species. Bioresour. Technol. 100 (2009) 5846-5852.

[13] S.L. Lim, T.Y. Wu, P.N. Lim, K.P.Y. Shak, The use of vermicompost in organic farming: overview, effects on soil and economics. J. Sci. Food Agric. 95 (2015) 1143-1156.

[14] S.A. Bhat, J. Singh, A.P. Vig, Vermiremediation of dyeing sludge from textile mill with the help of exotic earthworm Eisenia fetida Savigny. Environ. Sci. Pollut. Res. 20 (2013) 59755982.

[15] P.N. Lim, T.Y. Wu, C. Clarke, N.N. Nik Daud, A potential bioconversion of empty fruit bunches into organic fertilizer using Eudrilus eugeniae. Int. J. Environ. Sci. Technol. 2 (2015) 2533-2544.

[16] K.S. Reddy, M.V. Shantaram, Potentiality of earthworms in composting of sugarcane by products. Asian J. Microbiol. Biotechnol. Environ. Sci. 7 (2005) 483-487.

[17] K. Parthasarathi, Aging of Press mud vermicast of Lampito mauritti (Kinberg) and Eudrilus eugeniae (Kinberg) - Reduction in microbial population and activity. J. Environ. Biol. 27 (2006) 221-223.

[18] P. Sangwan, C.P. Kaushik, V.K. Garg, Feasibility of utilization of horse dung spiked filter cake in vermicomposters using exotic earthworm Eisenia foetida. Bioresour. Technol. 99 (2008) 2442-2448.

[19] P. Sangwan, C.P. Kaushik, V.K. Garg, Vermiconversion of industrial sludge for recycling the nutrients. Bioresour. Technol. 99 (2008) 8699-8704.

[20] M. Prakash, N. Karmegam, Vermistabilization of pressmud using Perionyx ceylanensis Mich. Bioresour. Technol. 101 (2010) 8464-8468.

[21] R. Kumar, D. Verma, B. L. Singh, U. Kumar, Shweta, Composting of sugar-cane waste byproducts through treatment with microorganisms and subsequent vermicomposting. Bioresour. Technol. 101 (2010) 6707-6711.

[22] P. Sangwan, C.P. Kaushik, V.K. Garg, Vermicomposting of sugar industry waste (pressmud) mixed with cow dung employing an epigeic earthworm Eisenia foetida. Waste Manage. Res. 28 (2010) 71-75.

[23] M. Honarvar, S. Samavat, M.H. Davoodi, K.H. Karimi, Possibility of producing compost and vermicompost from sugar beet waste in the sugar factory. J. Food Technol. Nutr. 8 (2011) 4653.

[24] J.M. Cynthia, K.T. Rajeshkumar, A study on sustainable utility of sugar mill effulent to vermicompost. Adv. Appl. Sci. Res. 3 (2012) 1092-1097.

[25] N.P. Pandit, S.K. Maheshwaria, Optimization of vermicomposting technique for sugarcane waste management by using Eisenia fetida. Int. J. Biosci. 10 (2012) 143-155.

[26] R. Niyazi, S. Chaurasia, Vermistabilization of fly ash amended with pressmud by employing eisenia foetida. Int. J. Pharm. Chem. Biol. Sci. 4 (2014) 85-95. 
[27] N.P. Pandit, S.K. Maheshwaria, Vermiremediation of sugarcane by-products into nutrient rich vermicompost through enhancing the bioconversion efficiency of Eisenia fetida by developing vermireactors. J. Bioprocess Technol. 99 (2014) 327-337.

[28] R.U. Shah, M. Abid, M.F. Qayyum, R. Ullah, Dynamics of chemical changes through production of various composts/vermicompost such as farm manure and sugar industry wastes. Int. J. Recycl. Org. Waste Agricult. 4 (2015) 39-51.

[29] R.M. Venkatesh, T. Eevera, Mass reduction and recovery of nutrients through vermicomposting of fly ash. Appl Ecol Environ Res 6 (2008) 77-84.

[30] V.K. Garg, R. Gupta, A. Yadav, Potential of Vermicomposting technology in solid waste management. In: Pandey A et al (ed) Current developments in solid state fermentation. AsiaTech. Publishers Inc., New Delhi, (2007) pp 468-511.

[31] S.S. Lim, J.W. Jung, W.J. Choi, H.M. Ro HM, Substrate quality effects on decomposition of three livestock manure composts with similar stability degree in an acid loamy soil. Korean J. Soil Sci. Fert. 44 (2011) 527-533.

[32] N. Senesi, Composted materials as organic fertilizers. Sci. Total Env. 81 (1989) 521-524.

[33] J. Singh, A. Kaur, A.P. Vig, P.J. Rup PJ, Role of Eisenia fetida in rapid recycling of nutrients from bio sludge of beverage industry. Ecotoxicol. Environ. Saf. 73 (2010) 430-435.

[34] K. Parthasarathi, Influence of moisture on the activity of Perionyx excavatus (Perrier) and microbial-nutrient dynamics of pressmud vermicompost. Iran. J. Environ. Health Sci. Eng. 4 (2007) 147-156.

[35] S. Suthar, Pilot-scale vermireactors for sewage sludge stabilization and metal remediation process: comparison with small-scale vermireactors. Ecol. Eng. 36 (2010) 703-712.

[36] T.C. Loh, Y.C. Lee, J.B. Liang, D. Tan, Vermicomposting of cattle and goat manures by Eisenia foetida and their growth and reproduction preference. Bioresour. Technol. 96 (2005) 111-114.

[37] C.A. Edwards, Breakdown of animal, vegetable and industrial organic wastes by earthworms; In CA Edwards and EP Neuhauser (eds), Earthworms in Waste and Environmental Management. SPB Academic Publishing, The Hague, the Netherlands. (1988) pp 21-31.

[38] S. Suthar, Potential utilization of Guar gum industrial waste in vermicompost production. Bioresour. Technol. 97 (2006) 2474-2477. 